\title{
The biological treatment method for landfill leachate
}

\author{
Siti Ilhami Firiyal Imtinan ${ }^{1 *}, P$. Purwanto ${ }^{1,2}$, Bambang Yulianto ${ }^{1,3}$ \\ ${ }^{1}$ Master Program of Environmental Science, School of Postgraduate Studies, Diponegoro University, \\ Semarang - Indonesia \\ ${ }^{2}$ Department of Chemical Engineering, Faculty of Engineering, Diponegoro University, Semarang - \\ Indonesia \\ ${ }^{3}$ Department of Marine Sciences, Faculty of Fisheries and Marine Sciences, Diponegoro University, \\ Semarang - Indonesia
}

\begin{abstract}
Currently, waste generation in Indonesia is increasing; the amount of waste generated in a year is around 67.8 million tons. Increasing the amount of waste generation can cause other problems, namely water from the decay of waste called leachate. Leachate can contaminate surface water, groundwater, or soil if it is streamed directly into the environment without treatment. Between physical and chemical, biological methods, and leachate transfer, the most effective treatment is the biological method. The purpose of this article is to understand the biological method for leachate treatment in landfills. It can be concluded that each method has different treatment results because it depends on the leachate characteristics and the treatment method. These biological methods used to treat leachate, even with various leachate characteristics, also can be combined to produce effluent from leachate treatment below the established standards.
\end{abstract}

Keywords. Leachate treatment; biological method; landfill leachate.

\section{Introduction}

Waste generation in Indonesia is increasing, as stated by the Minister of Environment and Forestry, which recognizes the challenges of waste problems in Indonesia are still very large. The amount of waste generated in a year is around 67.8 million tons and will continue to grow in line with population growth [1]. Waste that is produced will usually be taken to the landfill. Increasing the amount of waste generation can cause other problems, namely water from the decay of waste called leachate. The liquid contains an exaggerated of non-biodegradable and biodegradable materials, including phosphate, sulfide, ammonia nitrogen, phenols, organic matter, and heavy metals called landfill leachate [2]. Leachate produced can pollute the environment if it is streamed directly into water bodies and

\footnotetext{
* Corresponding author: sitiilhamifiriyal@students.undip.ac.id
} 
without treatment so that pollutants in leachate can contaminate surface water, groundwater, or soil. In addition to impacting the environment, this pollution can also affect public health that uses river water or well water as a water source for daily needs. Then it is necessary to conduct leachate treatment.

There are some stages in the process of leachate treatment, including treatment with the biological method. Between physical and chemical, biological methods, and leachate transfer, the most effective treatment is the biological method [3]. In the treatment of leachate with biological processes, there are various methods, such as trickling filter, rotating biological contactor, aerated lagoon, upflow anaerobic sludge blanket, activated sludge, and sequencing batch reactor. This article aims to understand the biological method for landfill leachate treatment and, in this study, data and information obtained through literature studies based on journals, books, or previous research.

\section{Landfill leachate}

Landfill leachate, a water product that requires effective treatment before being released to the environment. Landfill leachate can also be absorbed and contain various pollutants. The quantity and quality of leachate can be seen from its characteristics, where leachate's quantity can be influenced by multiple factors, including groundwater infiltration, rainfall, and surface runoff. Another important factor is climate, which determines the occurrence of evaporation and precipitation $[4,5]$. While leachate's quality, in general, can be determined by the basic parameters measured, such as biochemical oxygen demand, ammonia, suspended solids, $\mathrm{pH}$, and chemical oxygen demand. Each parameter's measurement results depend on the landfill's age, climate, rainfall, and the ingredients of the waste entering the landfill [5]. The leachate is a liquid formed by water in the residue of organic matter and due to the presence of natural moisture. Besides, it is the result of the organic matter biodegradation by the infiltration of water from the landfill cell layer [6].

\section{Landfill leachate characteristics}

Landfill leachate contains large quantities of inorganic and organic compounds that can cause pollution. Due to a pollutant, it is necessary to treated landfill leachate before being discharged. The location of the landfill can determine the qualities and quantities of leachate. As a result of complex compositions, the leachate quality has characteristics that contain high levels of contaminants, toxic aromatic compounds, and organic macromolecules. Other characteristics of leachate water quality are contained nitrogen ammonia, organic matter, high heavy metal concentration, nutritional imbalance, and have low phosphorus content. In addition to quality, the characteristic of leachate quantity is influenced by the rainy season, where high rainfall areas can have a higher organic content [7-9]. The leachate contains toxic or non-toxic compounds such as aromatic hydrocarbons, also contains organic compounds, and xenobiotic organic compounds, the most common are aromatic compounds such as toluene, benzene, xylene, and ethylbenzene. Also, it contains nitrogen ammonia, low phosphorous content, and heavy metal. Leachate also contains total dissolved solids with high concentrations and large amounts of microorganisms. Also, leachate has a pH between 6 and 7 and has a weak acidity. Then the leachate also contains high chroma and is black, dark brown, or brown, with a powerful odor [10]. 


\section{Landfill leachate treatment}

One environmental problem that needs attention is leachate from landfill activities. It has a high content of inorganic and organic compounds and can impact the environment. However, because organic pollutants in the leachate have high content, it makes the methods applied themselves inefficiently. The leachate treatment method needs to include physical and chemical pre-treatment as well as aerobic and anaerobic processes in the biochemical process, then end with the physical and chemical process [9, 11]. The combination of aerobic, anaerobic, coagulation, sedimentation, and electrolysis methods formed to treat landfill leachate because it has complex compositions with high biological toxicity. Also, because the leachate must be appropriately processed before it is released into the environment, besides, to determine the appropriate methods or technologies in the treatment of leachate, it is necessary to know the age of the landfill and other characteristics such as $\mathrm{COD}$, the ratio of $\mathrm{BOD} / \mathrm{COD}$, and others $[12,13]$.

\section{Biological treatment method}

Young leachate usually has a relatively high COD and BOD concentration, where the COD content can be reduced with biological methods by up to $50 \%$. Biological leachate treatment is an effective method for reducing organic compounds that can biodegrade in the leachate. The biological treatment method in the landfill leachate is currently an adaptation of the wastewater treatment method [14].

\subsection{Trickling filter}

The trickling filter is aerobic, easy to construct, and operate for wastewater treatment. It is widely used in industrial wastewater treatment and domestic waste treatment. The process consists of the effluent that passing and treated over a fixed bed. On the surface of the media, biological films are growing. Stabilizing the organic component of waste requires a film of biological activity. Also, biofilms are exposed to air for oxygen uptake and have contact time with wastewater. Treatment using the trickling filter method is said to have lower yields than other treatment methods. However, treatment methods with trickling filters can be used for processing various types of landfill leachate. Leachate treatment using a trickling filter can produce effluents with a significant reduction of ammonia $59.50 \%$, turbidity $71.96 \%$, BOD $576.69 \%$, and suspended solids $73.17 \%$ [15-17].

\subsection{Rotating biological contractor}

Bioreactors with an attached growth and consist of a series of discs at close range and installed on a general horizontal shaft and partly immersed in a tank where wastewater flows called the rotating biological contactor (RBC). Then the mechanical motor rotates the shaft, and biofilms are made on the entire surface of the disk, which metabolizes organic wastewater material. Oxygen diffusion occurs in biofilms because biofilms attached come from wastewater and are exposed to atmospheric air. When immersed in wastewater and microorganisms consume oxygen for their cellular respiration and growth and organic material, organic material and nutrients are present diffuse in soluble form in biofilms. RBC has been proved a prominent treatment process for removing ammonia and $\mathrm{BOD}_{5}$. The attached growth of microorganisms provides a large surface area for the biodegradation of organic matter. $\mathrm{RBC}$ is an effective alternative process due to the low sludge production, large microbial surface area, high volumetric rate, and less operational and maintenance 
cost. Activated sludge and rotating biological contactor produce high-quality effluents, but $\mathrm{RBC}$ can handle toxic and shock hydraulic and organic loadings in treating wastewater. The overall removal efficiency is about $90 \%$ for nitrogen removal and $99 \%$ for organic removal in $\mathrm{RBC}[18,19]$.

\subsection{Upflow anaerobic sludge blanket}

One method in environmental protection that has been recognized is the processing with an upflow anaerobic sludge blanket (UASB) method. This method is an efficient technology for wastewater treatment and connects the anticipation of anaerobic decomposition to reduce the volume of waste and biogas production. UASB has also been used in industry and agriculture. For continuous UASB reactors, the efficiency of dissolved chemical oxygen demand removal is consistently between $77 \%$ and $91 \%$ for all HRT [20, 21].

\subsection{Aerated lagoon}

The aerated lagoon is also one of the simple methods that can be used in landfill leachate treatment. This method is usually done by aeration through surface aerators or diffuse bubbles with aeration. Also, if the aerated lagoon is used as a full-scale leachate treatment, it must pay attention to the Hydraulic Retention Times (HRT) because with HRT, the appropriate length of the aerated lagoon can eliminate ammonia and COD in large sizes. The aerated lagoon can also eliminate $\mathrm{N}$ load by around $80 \%$ [22].

\subsection{Activated sludge}

Another method that can be used in landfill leachate treatment is activated sludge. This method is a low-cost treatment, and the right solution for reducing total nitrogen, organic matter, and ammoniacal nitrogen. Another advantage of leachate treatment with the activated sludge method is that it can remove biodegradable organic materials effectively and convert them into water and carbon dioxide. Besides, the activated sludge method can be carried out aerobically and anaerobically. Activated sludge with the anaerobic process is capable of producing energy and has low energy consumption. However, the drawback is that the resulting effluent has a high COD level, and there are still some organic materials. Meanwhile, activated sludge with the aerobic processes can produce good effluent quality and high levels of organic removal but high energy consumption in the treatment process [9].

\subsection{Sequencing batch reactor}

The improvement of treatment using the activated sludge method is called sequencing batch reactor or SBR. The processing with SBR has steps, including filling, aeration, sedimentation, and decantation. Although SBR has a simple design, this method can produce high-quality effluents, because, in the system, there are equalization tanks, reactors, and purifiers. The treatment of leachate with the SBR method is a suitable technology in biological treatment. Besides, it has high $\mathrm{N}$ removal ability and COD removal, on average, around 30-40\%. Sequencing batch reactor can release effluent with reductions in suspended solids $62.28 \%$, ammonia $64.83 \%$, and $\mathrm{BOD}_{5} 84.06 \%$ [17, 23, 24]. 


\section{Landfill leachate treatment in Indonesia}

There are various landfills in Indonesia, where each landfill has different leachate characteristics. The leachate treatment methods in Indonesia are almost the same, where most of them use the biological method. Besides, the characteristics of leachate produced in Indonesia are above the specified quality standards. Because leachate treatment needs to be carried out before it flows, leachate treatment failure can be caused by poor management, lack of funds, and monitoring in the leachate treatment [25]. One of the landfills in Indonesia is the Cipayung Landfill. Stabilization pond is a method used in the leachate treatment plant at this landfill site. For the quality of leachate from this landfill, there are still parameters that exceed the established standards. Where produced $\mathrm{pH} 7.83$, temperature $34.81^{\circ} \mathrm{C}$, total nitrogen $373.33 \mathrm{mg} / \mathrm{L}$, total suspended solid $72.33 \mathrm{mg} / \mathrm{L}$, COD $6,860 \mathrm{mg} / \mathrm{L}$, BOD $3,959.63 \mathrm{mg} / \mathrm{L}$, and mercury $0.0016 \mathrm{mg} / \mathrm{L}$. The leachate treatment plant at this landfill does not meet the design criteria [26].

Another landfill in Indonesia is the Jatibarang Landfill. The leachate characteristics in this landfill include pH 7.45, COD $2390 \mathrm{mg} / \mathrm{L}$, ammonia $23 \mathrm{mg} / \mathrm{L}$, BOD $468.1 \mathrm{mg} / \mathrm{L}$, and total suspended solid $774 \mathrm{mg} / \mathrm{L}$ [27]. Leachate in Jatibarang Landfill contains nonbiodegradable organic compounds and ammonia. The leachate treatment plant in this landfill failed to remove organic matter and ammonia significantly. So, a combination of evapotranspiration and anaerobic systems would solve leachate in Jatibarang Landfill. Combination processes with evapotranspiration and microbial would be promising [28]. Leachate in landfills containing high levels of ammonium can be treated using an evapotranspiration-anaerobic system because this system is better in reducing the ammonium content gradually. There are several types of plants that can be used in reducing the ammonia content with the evapotranspiration system, including Eleusine indica, Alocasia macrorrhiza, and Fimbristylis globulosa [29, 30].

\section{Recommendation}

It can be concluded that each method has different treatment results because it based on the leachate characteristics and the treatment method. Besides, previous studies obtained results, such as leachate treatment using a trickling filter produce effluents with a significant reduction of ammonia $59.50 \%$, turbidity $71.96 \%$, BOD $76.69 \%$, and suspended solids $73.17 \%$. Sequencing batch reactor can release effluent with reductions in suspended solids $62.28 \%$, ammonia $64.83 \%$, and $\mathrm{BOD}_{5} 84.06 \%$ [17]. The overall removal efficiency is about $99 \%$ for organic removal and $90 \%$ for nitrogen removal in RBC [19]. For continuous UASB reactors, the efficiency of dissolved chemical oxygen demand removal is consistently between $77 \%$ and $91 \%$ [21]. The aerated lagoon can eliminate ammonia and COD in large sizes and eliminate $\mathrm{N}$ load by around $80 \%$ [22]. Treatment of leachate using the activated sludge includes reducing total nitrogen, organic matter, and ammoniacal nitrogen [9]. These methods can be used for landfill leachate treatment even with various leachate characteristics. Also, these methods can be combined to produce effluent from landfill leachate treatment below the established standards.

Based on the above problem, the recommendation given is to consider leachate treatment plant design, and it needs to be monitored regularly. The leachate treatment plant's design should be adjusted to the leachate characteristics and the landfill location because these factors can determine leachate qualities and quantities. It is necessary to combine several methods to obtain effluent with characteristics that are below the established standards. The various biological methods described earlier can also be incorporated in leachate treatment plant designs and complemented by physical and chemical methods. 


\section{References}

1. Kementerian Lingkungan Hidup dan Kehutanan, Indonesia memasuki era baru pengelolaan sampah, PPID KLHK (2020)

2. M. A. Kamaruddin, M. S. Yusoff, H. A. Aziz, Y. Hung, Sustainable treatment of landfill leachate, Appl. Water Sci. 5, 113-126 (2015)

3. C. Yuan, Y. Wang, T. Zhu, X. Feng, Y. Ma, F. Yu, Y. Xie, Multistage biological contact oxidation for landfill leachate treatment: Optimization and bacteria community analysis, Int. Biodeterior. Biodegradation 125, 200-207 (2017)

4. R. B. Brennan, M. G. Healy, L. Morrison, S. Hynes, D. Norton, E. Clifford, Management of landfill leachate : The legacy of European Union Directives, Waste Manag. 55, 355-363 (2016)

5. L. Miao, G. Yang, T. Tao, Y. Peng, Recent advances in nitrogen removal from landfill leachate using biological treatments - A review, J. Environ. Manage. 235, 178-185 (2019)

6. P. Yao, Perspectives on technology for landfill leachate treatment, Arabian J. Chem. 10, S2567-S2574 (2017)

7. Z. J. Yong, M. J. K. Bashir, C. A. Ng, S. Sethupathi, J. Lim, A sequential treatment of intermediate tropical landfill leachate using a sequencing batch reactor (SBR) and coagulation, J. Environ. Manage. 205, 244-252 (2018)

8. S. M. Iskander, R. Zhao, A. Pathak, A. Gupta, A. Pruden, J. T. Novak, Z. He, A review of landfill leachate induced ultraviolet quenching substances: Sources, characteristics, and treatment, Water Res. 145, 297-311 (2018)

9. K. Wang, L. Li, F. Tan, D. Wu, Treatment of landfill leachate using activated sludge technology: A review, Archaea (2018)

10. Z. Youcai, Pollution control technology for leachate from municipal solid waste, Butterworth-Heinemann (2018)

11. F. Ghanbari, J. Wu, M. Khatebasreh, D. Ding, K. A. Lin, Efficient treatment for landfill leachate through sequential electrocoagulation, electrooxidation and $\mathrm{PMS} / \mathrm{UV} / \mathrm{CuFe}_{2} \mathrm{O}_{4}$ process, Sep. Purif. Technol. 242, 116828 (2020)

12. A. Qiu, Q. Cai, Y. Zhao, Y. Guo, L. Zhao, Evaluation of the treatment process of landfill leachate using the toxicity assessment method, Int. J. Environ. Res. Public Health 13, 1262 (2016)

13. H. Luo, Y. Zeng, Y. Cheng, D. He, X. Pan, Recent advances in municipal landfill leachate: A review focusing on its characteristics, treatment, and toxicity assessment, Sci. Total Environ. 703, 135468 (2020)

14. J. Gao, V. Oloibiri, M. Chys, W. Audenaert, B. Decostere, Y. He, H. V. Langenhove, K. Demeestere, S. W. H. V. Hulle, The present status of landfill leachate treatment and its development trend from a technological point of view, Rev. Environ. Sci. Biotechnol. 14, 93-122 (2015)

15. M. R. Vianna, G. C. B. de Melo, M. R. V. Neto, Wastewater treatment in trickling filters using Luffa cyllindrica as biofilm supporting medium, JUEE 6, 2, 57-66 (2012)

16. R. Matthews, M. Winson, J. Scullion, Treating landfill leachate using passive aeration trickling filters; effects of leachate characteristics and temperature on rates and process dynamics, Sci. Total Environ. 407, 2557-2564 (2009)

18. O. O. Aluko, M. K. C. Sridhar, Evaluation of leachate treatment by trickling filter and sequencing batch reactor processes in Ibadan, Nigeria, Waste Manag. Res. 31, 7, 700705 (2013)

19. V. Singh, A. K. Mittal, Characterization of biofilm of a rotating biological contactor treating synthetic wastewater, Water Sci. Technol. 66, 2, 429-437 (2012) 
20. S. Waqas, M. R. Bilad, A review on rotating biological contactors, Indonesian J. Sci. Technol. 4, 2, 241-256 (2019)

21. M. A. Latif, R. Ghufran, Z. A. Wahid, A. Ahmad, Integrated application of upflow anaerobic sludge blanket reactor for the treatment of wastewaters, Water Res. 45, 4683-4699 (2011)

22. K. J. Kennedy, E. M. Lentz, Treatment of landfill leachate using sequencing batch and continuous flow upflow anaerobic sludge blanket (UASB) reactors, Wat. Res. 34, 14, 3640-3656 (2000)

23. M. K. Mehmood, E. Adetutu, D. B. Nedwell, A. S. Ball, In situ microbial treatment of landfill leachate using aerated lagoons, Bioresour. Technol. 100, 2741-2744 (2009)

24. A. Spagni, S. Marsili-Libelli, M. C. Lavagnolo, Optimisation of sanitary landfill leachate treatment in a sequencing batch reactor, Water Sci. Technol. 58, 2, 337-343 (2008)

25. Y. J. Chan, M. F. Chong, C. L. Law, Biological treatment of anaerobically digested palm oil mill effluent (POME) using a Lab-Scale Sequencing Batch Reactor (SBR), J. Environ. Manage. 91, 1738-1746 (2010)

26. N. Emalya, E. Munawar, W. Rinaldi, Y. Yunardi, Landfill leachate management in Indonesia: A review, IOP Conf. Ser.: Mater. Sci. Eng. 845 (2020)

27. E. Noerfitriyani, D. M. Hartono, S. S. Moersidik, I. Gusniani, Leachate characterization and performance evaluation of leachate treatment plant in Cipayung landfill, Indonesia, IOP Conf. Ser.: Earth Environ. Sci. 106 (2018)

28. W. Oktiawan, I. B. Priyambada, R. Ardhianto, Treatment of leachate using electrocoagulation technology; study case in Jatibarang Landfill-Semarang City, IOP Conf. Ser.: Earth Environ. Sci. 448 (2020)

29. B. Zaman, Purwanto, S. Mangkoedihardjo, Potential treatment system for ammonia in leachate, a case study for Jatibarang Landfill, Central Java, J. Appl. Environ. Biol. Sci. 2, 7, 320-325 (2012)

30. B. Zaman, P. Purwanto, S. Mangkoedihardjo, Reversible anaerob-evapotranspiration process for removal of high strength ammonium in leachate from tropical landfill, Adv. Sci. Lett. 23, 3, 2586-2588 (2017)

31. B. Zaman, Purwanto, S. Mangkoedihardjo, Plant growth rate in evapotranspiration continuous system reactors as the 2 nd treatment at anaerobic-evapotranspiration system with high strength ammonium in leachate influent, Internat. J. Sci. Eng. 7, 1, 48-51 (2014) 